\title{
The role of fibroblast growth factor receptor 4 overexpression and gene amplification as prognostic markers in pediatric and adult adrenocortical tumors
}

\section{Dear Editor}

In the last decade, relevant progresses in the molecular basis of adrenocortical tumors (ACTs) were achieved and abnormalities involving growth pathway deregulation were frequently associated with malignancy. Remarkably, upregulation of insulin-like growth factor 2 (IGF2) and its receptor $(I G F 1 R)$ has been demonstrated in a significant proportion of ACTs, and the presence of these abnormalities has both prognostic and therapeutic implications (Almeida et al. 2008). In fact, clinical trials involving pharmacological blockade of IGF1R are currently under process. Besides the IGF system, other growth signaling pathways have been suggested to be important for ACC progression and are possible therapeutic targets. Among these, fibroblast growth factor receptor 4 (FGFR4) overexpression has been observed in both adult and pediatric ACT by genome-wide expression studies in the same extent as the IGF system (de Fraipont et al. 2005, Laurell et al. 2009). However, these data have not been validated in an independent cohort and the molecular mechanisms responsible for FGFR 4 upregulation have not been assessed. Therefore, we studied the expression levels of FGFR4 and gene amplification in a cohort of ACT patients from our institution. This study was approved by the Ethics Committee of Hospital das Clinicas, Sao Paulo, Brazil, and an informed written consent was obtained from all patients and/or parents. Our cohort consisted of 57 patients -32 adults (age $\geq 18$ years, 18-66 years) and 25 pediatric (age $<18$ years, $0.9-17$ years) with the diagnosis of ACT, with a mean follow-up period of $77.5 \pm 53$ months. FGFR4 transcript levels were assessed through quantitative real-time RT-PCR in all 57 samples using TaqMan gene expression assays (Applied Biosystem, Foster City, CA, USA). The endogenous control gene used was $A C T B$ for each sample and the reactions were carried out in triplicate. The relative expression levels of FGFR4 were calculated using the $2^{-\Delta \Delta C_{t}}$ method as described previously (Livak \& Schmittgen 2001). A commercial pool of 61 human adrenal glands of autopsy was the reference sample (Clontech). The criteria used for underand overexpression was a twofold change in comparison with the reference sample. FGFR4 amplification was determined using the SALSA MLPA kit P026-C1 Sotos (MRC-Holland, Amsterdam, The Netherlands), which contains two probes for FGFR4 gene and 24 probes for NSD1 gene at locus 5q35.1. FGFR4 copy number was assessed in 45 ACTs. MLPA was performed as described previously (Schouten et al. 2002). The tumor samplenormalized peak height was divided by the average normalized peak height from normal adrenals. Dosage quotient areas outside the range $0.70-1.3$ were considered abnormal. Control samples were included in each multiplex ligation-dependent probe amplification (MLPA) experiment. Each result was confirmed by two independent tests.

Overall, FGFR4 overexpression was detected in $65 \%$ (37 out of 57) of the cases. Noteworthy, there was a positive correlation between FGFR4 and IGF2 expression levels (Pearson's $r=0.84, P<0.001$ ). This finding is in accordance with previous data (de Fraipont et al. 2005), which suggested that FGFR4 and IGF2 belong to a cluster of genes that are simultaneously overexpressed in adrenocortical carcinoma (ACC). Among the 25 pediatric ACTs, FGFR4 overexpression was detected in all except three cases ( $88 \%)$. In the adult group, FGFR4 overexpression was detected in $47 \%$ (15 out of 32) of ACTs, being significantly different between carcinomas and adenomas (9.35 (0.2135.73) vs 1.44 (0.53-9.85); Mann-Whitney $U$ test, $P=0.004$ ). Survival analysis revealed that FGFR4 overexpression was a predictor of poor outcome in adult patients (log rank test, $P=0.049$; Fig. $1 \mathrm{~A}$ ). In addition, FGFR 4 amplification was detected in three out of $22(13.5 \%)$ of the pediatric tumors and in seven out of $23(30.4 \%)$ of adult tumors, suggesting that gene amplification may be the molecular mechanism underlying FGFR4 overexpression in a subset of tumors. Furthermore, FGFR4 locus amplification was associated with adverse outcome in adults (log rank test, $P=0.008$; Fig. 1B).

We demonstrated FGFR4 overexpression in a significant proportion of pediatric and adult ACTs, 

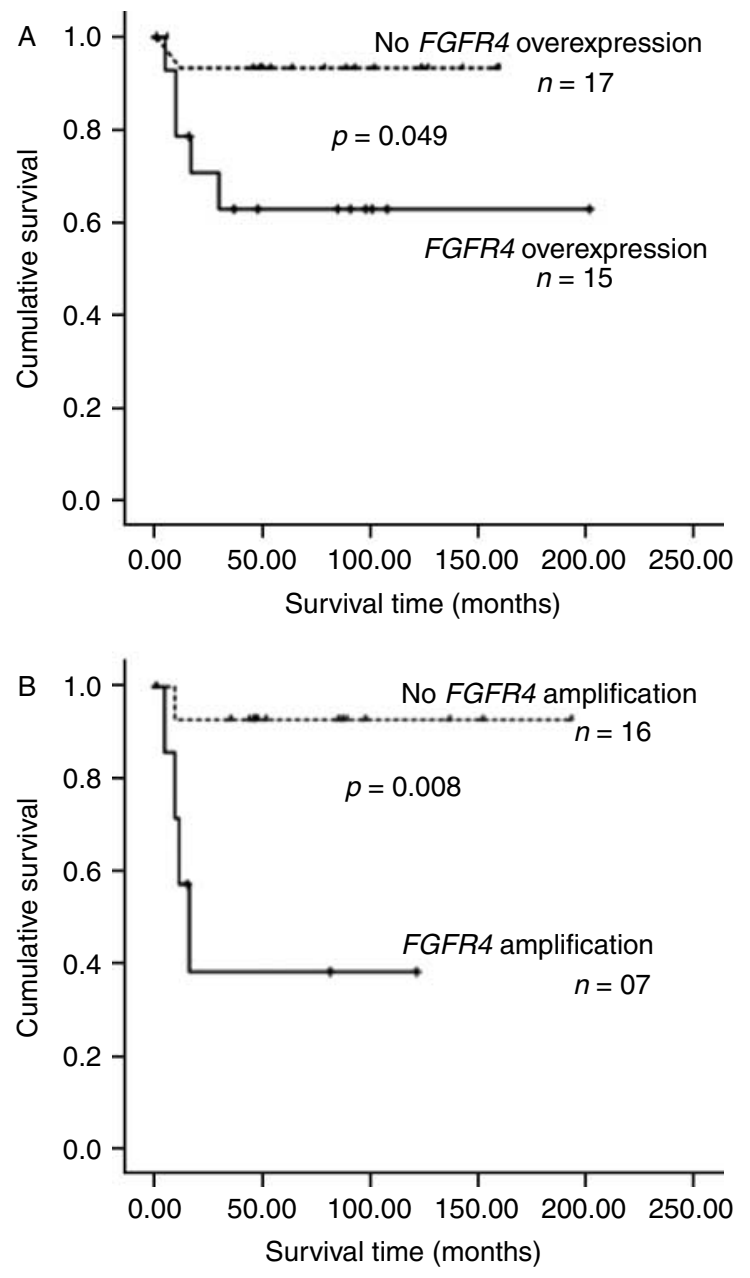

Figure 1 Kaplan-Meier survival analysis of adult patients with adrenocortical tumors. (A) Overall survival of 32 patients (17 ACA and 15 ACC) according to FGFR4 expression level. (B) Overall survival of 23 patients (12 ACA and 11 ACC) according to the amplification status of FGFR4 locus. Survival time is expressed in months.

confirming previous observations (de Fraipont et al. 2005, West et al. 2007, Laurell et al. 2009). According to our data, we consider that FGFR4 overexpression and amplification may be important steps in adrenocortical tumorigenesis and FGFR4 is possibly an interesting therapeutic target.

$$
\begin{array}{r}
\text { Luciana Pinto Brito }^{1}, * \\
\text { Tamaya Castro Ribeiro }^{1}, \\
\text { Madson Q Almeida }^{2} \\
\text { Alexander Augusto de Lima Jorge } \\
\text { Iberê Cauduro Soares } \\
{ }^{4} \\
\text { Ana Claudia Latronico } \\
\end{array}
$$

\section{${ }^{1}$ Unidade de Endocrinologia do Desenvolvimento, \\ Laboratorio de Hormonios e Genetica Molecular LIM/42,}

Faculdade de Medicina da Universidade de Sao Paulo, Avenida Dr Enéas de Carvalho Aguiar, No. 155 PAMB, $2^{\circ}$ Andar, Bloco 6, Sao Paulo CEP 05403-900, Brazil

${ }^{2}$ Unidade de Suprarrenal, Disciplina de Endocrinologia, Faculdade de Medicina da Universidade de Sao Paulo, Sao Paulo, Brazil

${ }^{3}$ Unidade de Endocrinologia Genética LIM/25, Disciplina de Endocrinologia Faculdade de Medicina da Universidade de Sao Paulo, Sao Paulo, Brazil

${ }^{4}$ Divisão de Anatomia Patológica do Hospital das Clínicas LIM/14, Faculdade de Medicina da Universidade de Sao Paulo, Sao Paulo, Brazil

(Correspondence should be addressed to AM Lerario; Email: amlerario@gmail.com)

*(LP Brito and TC Ribeiro contributed equally to this work)

\section{Declaration of interest}

The authors declare that there is no conflict of interest that could be perceived as prejudicing the impartiality of the research reported.

\section{Funding}

This work was supported in part by Fundação de Amparo a Pesquisa do Estado de São Paulo (FAPESP), grant number 08/51618-6.

\section{References}

Almeida MQ, Fragoso MC, Lotfi CF, Santos MG, Nishi MY, Costa MH, Lerario AM, Maciel CC, Mattos GE, Jorge AA et al. 2008 Expression of insulin-like growth factor-II and its receptor in pediatric and adult adrenocortical tumors. Journal of Clinical Endocrinology and Metabolism 93 3524-3531. (doi:10.1210/jc.2008-0065)

de Fraipont F, El Atifi M, Cherradi N, Le Moigne G, Defaye G, Houlgatte R, Bertherat J, Bertagna X, Plouin PF, Baudin E et al. 2005 Gene expression profiling of human adrenocortical tumors using complementary 
deoxyribonucleic acid microarrays identifies several candidate genes as markers of malignancy. Journal of Clinical Endocrinology and Metabolism 90 1819-1829. (doi:10.1210/jc.2004-1075)

Laurell C, Velazquez-Fernandez D, Lindsten K, Juhlin C, Enberg U, Geli J, Hoog A, Kjellman M, Lundeberg J, Hamberger B et al. 2009 Transcriptional profiling enables molecular classification of adrenocortical tumours. European Journal of Endocrinology 161 141-152. (doi:10.1530/EJE-09-0068)

Livak KJ \& Schmittgen TD 2001 Analysis of relative gene expression data using real-time quantitative PCR and the
2(-Delta Delta C(T)) method. Methods 25 402-408. (doi:10.1006/meth.2001.1262)

Schouten JP, McElgunn CJ, Waaijer R, Zwijnenburg D, Diepvens F \& Pals G 2002 Relative quantification of 40 nucleic acid sequences by multiplex ligation-dependent probe amplification. Nucleic Acids Research 30 e57. (doi:10.1093/nar/gnf056)

West AN, Neale GA, Pounds S, Figueredo BC, Rodriguez Galindo C, Pianovski MA, Oliveira Filho AG, Malkin D, Lalli E, Ribeiro R et al. 2007 Gene expression profiling of childhood adrenocortical tumors. Cancer Research 67 600-608. (doi:10.1158/0008-5472.CAN-06-3767) 